УДК 786.1

DOI https://doi.org/10.31723/2524-0447-2020-30-1-20

\author{
Наталія Борисівна Язикова \\ ORCID: 0000-0002-6259-9798 \\ кандидат педагогічних наук,
}

доцент кафедри загального та спеціалізованого фортепіано

Одеської національної музичної академії імені А. В. Нежданової

nataly.yazykova19@gmail.com

\title{
ТЕОРЕТИЧНІ ОСНОВИ ФОРМУВАННЯ МУЗИЧНО-ВИКОНАВСЬКИХ УМІНЬ У КЛАСІ ЗАГАЛЬНОГО ТА СПЕЦІАЛІЗОВАНОГО ФОРТЕПІАНО
}

\begin{abstract}
Мета роботи - теоретично обгрунтувати актуальність необхідності формування виконавських навичок гри на фортепіано у студентів-непіаністів вищих музичних закладів у рамках компетентнісного підходу щодо єдиної загальнодержавної стратегії розвитку освіти. Методологія дослідження - науково-теоретичні концепції у сфері мистецької освіти, музичної педагогіки та виховання, мистецтвознавства; теоретико-методологічні основи педагогіки мистецтва; наукові праці, присвячені розв 'язанню основних проблем теорії та методики фортепіанної педагогіки та виконавства. Наукова новизна дослідження полягає у визначенні значущості інтегрованих зв 'язків між означеною дисципліною та дисциплінами фахової спрямованості у процесі навчання здобувачів вищої освіти 1 (бакалаврського) рівня спеціальності 025 «Музичне мистецтво». Доведено доцільність опанування студентами різних спеціалізацій умінь гри на фортепіано, гри ансамблем, акомпанування. Уточнено поняття «виконавські вміння гри на фортепіано у класі загального та спеціалізованого фортепіано». Висновки. Виконавські вміння гри на фортепіано у класі загального та спеціалізованого фортепіано визначаються якістю сформованості компонентів інтерпретаційної діяльності, що формуються у процесі виконання фортепіанних творів; базуються на досвіді, особистісних психофізичних якостях, музичних здібностях та впливають на професійне становлення студентів; розвиток умінь гри на фортепіано є необхідним компонентом музичного навчання студентів за всіма спеціалізаціями; специфіка викладання дисципліни «Загальне та спеціалізоване фортепіано» базується на принципах розвивального й інтегрованого навчання, які позитивно впливають на музичне виховання студентів, забезпечують розвиток професійно значущих теоретичних знань, інтерпретаційних умінь, необхідних для вдосконалення виконавської майстерності в рамках основної спеціалізації; доцільність використання методів роботи у класах загального та спеціалізованого фортепіано зумовлена вимогами та специфікою навчання у класі з основної спеціалізації.

Ключові слова: дисиипліна «Загальне та спеціалізоване фортепіано», студент-непіаніст, акомпанемент, ансамбль, гра на фортепіано, виконавські вміння, професійна спеціалізація.
\end{abstract}

Yazykova Nataliia Borysivna, Candidate of Pedagogical Sciences, Assistant Professor at the Department of General and Specialized Pianos of the Odessa National A. V. Nezhdanova Academy of Music

Theoretical fundamentals of formation of music-performance skills in studens-nonpianists in the class of general and spezialized piano

Research objective to theoretically substantiate the relevance of the competency approach to the need for the formation of performing skills of piano playing in students-nonpianists of higher music institutions. The methodology of the study are scientific and theoretical concepts in the field of art education, music pedagogy and education, art history; theoretical and methodological foundations of art pedagogy; scientific works devoted to solving the main problems of the theory and methods of piano pedagogy and performance. The scientific novelty of the research is the manifestation of integrated connections of the discipline "General and specialized piano" with the disciplines of professional orientation in the process of teaching students majoring in 025 "Musical Arts". The expediency of mastering by students of different specializations the skills of playing the piano, playing in an ensemble and accompaniment has been substantiated; the concept of "performing skills of playing the piano in the class of general and specialized piano" has been clarified. Conclusions. A retrospective analysis of the scientific, theoretical and methodological literature on the problem of the formation of performing skills in playing the piano in the classes of the discipline "General and specialized piano" allows us to formulate the following conclusions: performing skills of playing the piano in the class of general and specialized piano is as automated components of performance, which are produced in the process of performing piano works; are based on experience, personal psychophysical qualities, musical abilities of students and influence their professional development in the chosen specialization; acquisition of piano skills is a necessary component of music education in all specializations; the specifics of teaching the discipline "General and Specialized Piano" is based on the principles of developmental learning, integrative processes, which, in turn, promotes general music education of students and ensures the development of professional music-theoretical knowledge, performing skills, which are

(c) Язикова Н. Б., 2020 
necessary components on the main specialization; the expediency of using methods of work in general classes of piano playing is determined by their adaptation to the requirements of specialization of students.

Key words: discipline "General and specialized piano", student-nonpianist, accompaniment, ensemble, piano playing, performing skills, professional specialization.

Языкова Наталия Борисовна, кандидат педагогических наук, доцент кафедры общего и специализированного фортепиано Одесской национальной академии имени А. В. Неждановой

Теоретические основы формирования музыкально-исполнительских навыков в классе общего и специализированного фортепиано

Цель работы - теоретически обосновать актуальность необходимости формирования исполнительских навыков игры на фортепиано у студентов-непианистов высших музыкальных заведений в рамках компетентностного подхода единой общегосударственной стратегии развития образования. Методология исследования - научно-теоретические концепции в сфере художественного образования, музыкальной педагогики и воспитания, искусствоведения; теоретико-методологические основы педагогики искусства; научные труды, посвященные решению основных проблем теории и методики фортепианной педагогики и исполнительства. Научная новизна исследования заключается в выявлении значимости интегрированных связей между обозначенной дисциплиной и дисциплинами профессиональной направленности в процессе обучения соискателей высшего образования 1 (бакалаврского) уровня специальности 025 «Музыкальное искусство». Доказана иелесообразность овладения студентами различных специализаций умениями интерпретации, ансамблевого музицирования, игры на фортепиано, аккомпанемента. Уточнено понятие «исполнительские умения игры на фортепиано в классе «Общего и специализированного фортепиано». Выводы. Ретроспективный анализ научно-теоретической, методической литературы по проблеме формирования исполнительских умений игры на фортепиано на занятиях по дисииплине «Общее и специализированное фортепиано» позволяет сформулировать следующие выводы: исполнительские умения игры на фортепиано в классе общего и специализированного фортепиано определяются качеством сформированности компонентов исполнительской деятельности, развиваются в процессе интерпретации фортепианных произведений; базируются на опыте, личных психофизических качествах, музыкальных способностях и влияют на профессиональное становление студентов; развитие умений игры на фортепиано является необходимым компонентом музыкального обучения студентов всех специализаций; специфика преподавания дисциплины «Общее и специализированное фортепиано» базируется на принципах развивающего и интегрирующего обучения, что способствует общемузыкальному воспитанию студентов, обеспечивает развитие профессионально значимых теоретических знаний, интерпретационных умений, необходимых для совершенствования исполнительского мастерства в рамках основной спещиализации; целесообразность использования методов работы в классах общего и специализированного фортепиано обусловлена требованиями и спещификой обучения основной спещиализации.

Ключевые слова: дисциплина «Общее и специализированное фортепиано», студент-непианист, аккомпанемент, ансамбль, игра на фортепиано, исполнительские умения, профессиональная специализация.

Актуальність теми дослідження. Вимоги сучасності виводять на перший план особистість музиканта-виконавця, що володіє професійними компетентностями у сфері музичного мистецтва, які надають можливість опанування інструментарію для його подальшого застосування у сферах музичного виконавства, музичної педагогіки, науково-дослідницької діяльності в галузі мистецької освіти. Отже, потреби соціокультурного сьогодення передбачають посилення уваги у процесі виховання студента-музиканта до опанування суміжних сфер виконавського мистецтва. Вирішенню такого завдання сприяє дисципліна «Загальне та спеціалізоване фортепіано».

Ретроспективний аналіз літератури з теорії та практики викладання загального фортепіано дає підстави зробити висновок про неоднозначність підходів щодо розуміння доцільності впровадження в навчальну діяльність студентів вищезгаданої дисципліни. Так, шлях iii становлення у професійній освіті охоплює періоди від обов'язкової складової частини музичного навчання до нівелювання іiі значущості у зв’язку з вузькоспеціалізованим характером підготовки музикантів-виконавців. Історія відродження дисципліни «Загальне фортепіано» як потужного засобу розвитку художнього інтелекту та музичного мислення в середині XX ст. пов'язана з іменами Н. Загорного, В. Ниркової та Г. Ципіна.

Зараз опанування вміння гри на фортепіано стало не тільки обов'язковою умовою фахової підготовки студентів усіх спеціалізацій вищих музично-виконавських закладів, а й свідченням компетентності музиканта-професіонала. Актуальність проблеми опанування виконавських умінь у класі загального фортепіано виявляється сьогодні в розвідках нових методик та інноваційних технологій. 3 огляду на ці обставини вважаємо за необхідне виявити особливості впливу фортепіано-виконавських умінь, які опановують студенти на заняттях із дисципліни «Загальне фортепіано», на процес формування спеціалізованих умінь майбутніх музикантів-виконавців, оркестрантів, вокалістів, хормейстерів-диригентів. 
Історичні надбання світової музичної педагогіки, досвід видатних педагогів та музикантів засвідчують важливість формування виконавських умінь гри на фортепіано в контексті паралельного освоєння їх студентами всіх спеціалізацій. Означені питання широко представлені в дослідженнях вітчизняних учених. На думку К. Давидовського, З. Йовенка, К. Коленко, О. Лось, О. Новицької, Ю. Тарчинської та інших, формування в музиканта відповідних умінь забезпечує повноцінність загальноестетичної, інтелектуальної та виконавської діяльності у процесі професійного музичного навчання $[4 ; 6 ; 7 ; 9 ; 10 ; 15]$. Ю. Тарчинська підкреслює складність опанування піаністичної майстерності студентами-непіаністами (за термінологією О. Гольденвейзера), у своєму дисертаційному дослідженні наголошує на необхідності пошуку більш ефективних методик, спрямованих на посилення уваги до дисципліни «загальне фортепіано» у системі міждисциплінарних зв’язків [15].

Ще С. Фейнберг підкреслював специфічні особливості фортепіано (універсальність, фактурність, тембральну необмеженість, об’ємне оркестрове звучання, технічне оснащення) та вказував на придатність цього інструмента не тільки для втілення творчих задумів музиканта, а й для практичного застосування в навчанні та вихованні особистості взагалі [16, с. 1]. Саме ці властивості інструмента привели до виділення в системі професійного музичного навчання окремого курсу «Загальне фортепіано», який сьогодні йменуватиметься «Загальне та спеціалізоване фортепіано».

Мета дослідження - теоретично обгрунтувати актуальність необхідності формування виконавських навичок гри на фортепіано у студентів-непіаністів вищих музичних закладів у рамках компетентнісного підходу щодо єдиної загальнодержавної стратегії розвитку освіти. Методологію дослідження становлять науково-теоретичні концепції сфери мистецької освіти, музичної педагогіки та виховання, мистецтвознавства; теоретико-методологічні основи педагогіки мистецтва; наукові праці, присвячені розв'язанню основних проблем теорії та методики фортепіанної педагогіки та виконавства.

Наукова новизна дослідження полягає у виокремленні значущості інтегрованих зв'язків між означеною дисципліною та дисциплінами фахової спрямованості у процесі навчання здобувачів вищої освіти 1 (бакалаврського) рівня спеціальності 025 «Музичне мистецтво». Доведено доцільність опанування студентами різних спеціалізацій умінь гри на фортепіано, гри ансамблем, акомпанування. Уточнено поняття «виконавські вміння гри на фортепіано у класі загального та спеціалізованого фортепіано».

Виклад основного матеріалу. Шлях становлення «Загального фортепіано» у професійній освіті зазнав чималих змін: від обов'язкової складової частини професійних умінь майстра-універсала (в епоху старовинних клавішно-струнних інструментів) до малозначного відгалуження у структурі предметних складових частин фортепіанної педагогіки, що на початку попереднього сторіччя було спричинене диференціацією окремих музичних спеціальностей.

Лише у 80-ті pp. XIX ст. предмет «Загальне фортепіано» посів гідне місце в навчальних програмах вищих музичних закладів. За словами М. Рубінштейна, мета підготовки студентів консерваторій того часу полягала у вихованні музикантів-спеціалістів як у вузькому (профільному), так і в широкому сенсі [13]. За уставом консерваторії вказаної епохи наголошувалося на можливості кожного студента присвятити себе вивченню того чи іншого інструмента або предмета, але в будь-якому разі професійне навчання студентів мало включати спів хором, гру на фортепіано, історію й естетику музики [13].

Визначна співачка О. Амфітеатрова-Левицька вказувала на обов'язкову складову частину випускового іспиту з фортепіано для студентів-вокалістів, де вони повинні були виконувати не тільки акомпанемент твору напам'ять та в різних тональностях, а й етюди, сонати, хорові партитури [1, с. 71].

Незважаючи на прогресивні тенденції, професійна освіта початку XX ст. опинилась на шляху дилетантизму. Такий підхід у вищій школі передбачав управління та виконання певної діяльності за умов відсутності належних знань та професійної підготовки. П. Хазанов називає цей період у музичній освіті «агресивним дилетантизмом», підкреслює тим самим ситуативно-імпульсивний підхід взагалі в системі навчання та його негативний вплив на професійну музичну освіту [17]. Саме в цей період вивчення фортепіано студентами-непіаністами опинилося перед загрозою знищення.

Перші спроби з визначенням еквівалентного місця предмета «Загальне фортепіано» серед інших дисциплін пов'язані з іменами М. Вигодського, Н. Загорного. М. Вигодським започатковано теоретичні обгрунтування специфіки загального фортепіано як самостійної дисципліни. На думку вченого, вони полягали в такому: відмінність від спеціального 
фортепіано; відповідність форм роботи та репертуару спеціальності студентів; орієнтування процесу навчання на їхню різнобічну музичну діяльність; виховання освіченої культурної особистості [2, с. 6, 12].

Учений зазначав, що виконавець у процесі вивчення курсу загального фортепіано набуває вміння передавати все розмаїття музичних явищ, що властиві системі звукодобування профільної спеціалізації. Вищеозначену інтеграцію вмінь автор пов'язує з підвищенням «виконавської культури» студента, наголошує на залежності вибору методів навчання у класі загального фортепіано від професійної спрямованості студента [2, с. 6].

Незважаючи на розвиток теоретично-наукових міркувань у контексті окреслених питань, наступні декілька десятиліть курс «Загальне фортепіано» знову втрачає свої позиції. Це був час виведення на перший план постаті музиканта-соліста, зосередження уваги викладачів на підготовці вузькоспеціалізованих виконавців, унаслідок чого роль вказаної дисципліни знов почала зводитися керівниками навчальних закладів музичного спрямування до значення «другорядної» дисципліни.

У 80-ті рр. з поверненням ідеї виховання «музикантів широкого профілю», які володіють багатьма видами професійної діяльності, здійснився прорив в оцінюванні педагогами та вченими значення й можливостей курсу. У цей час з'являються дослідження, що виявляють мету та завдання дисципліни, розкривають іії міждисциплінарні зв’язки. Під керівництвом В. Ниркової вийшла «Програма з фортепіано для студентів різних спеціальностей», яка й досі є базовим документом для викладачів предмета музичних вишів [11]. Учена аналізує та розкриває сутність «Загального фортепіано» у контексті міждисциплінарних зв'язків, доводить практичну необхідність гри на фортепіано, іiї впливу на якісне осягнення предметів історико-теоретичної та спеціалізованої спрямованості. Висловлені у програмі методичні положення розвинуто в роботах 3 . Йовенко та Г. Ципіна [6; 18]. Важливим висновком досліджень учених було означення змістових відмінностей дисциплін загального та спеціального фортепіано, що дозволяло окреслити завдання курсу «Загальне фортепіано» у системі забезпечення теоретичної, методичної та виконавсько-інструментальної підготовки майбутніх виконавців та педагогів. 3. Йовенко зосереджує увагу на трьох основних положеннях: усі предмети навчального закладу підпорядковані меті підготовки студента певної професійної спрямованості; курс «Загальне фортепіано» призначений для вивчення представниками кожної з музичних спеціалізацій, крім піаністів; оптимізація навчання у класі «Загального фортепіано» залежить від варіативності методики викладання з урахуванням: спеціалізації студента, технічних можливостей кожного студента, часу, відведеного на вивчення даної дисципліни, наявності чи відсутності інструмента для домашніх занять [6].

Початок нового тисячоліття ознаменувався вимогами суспільства щодо суттєвих змін освітнього процесу. Стосовно музично-виконавської освіти - це забезпечення випускників нового покоління здатністю «розв'язувати складні спеціалізовані завдання та практичні проблеми в галузі музичної професійної діяльності, що передбачає застосування системи інтегрованих художньо-естетичних знань із теорії, історії музики, педагогіки і виконавства та характеризується комплексністю та невизначеністю умов» [14]. Виходячи з того, що розвиток особистості у процесі навчання стимулюється навчанням, питання навчання нині повинні вирішуватись з урахуванням перспективного впливу його результатів на розвиток особистості студентів-музикантів. У такій ситуації надзвичайно цінними і продуктивними видаються спільні пошуки музично-педагогічної науки та виконавської практики щодо переосмислення сутності принципу «міждисциплінарні зв'язки» у контексті інтеграційних процесів. Інтегроване навчання у класі загального фортепіано пов'язане із сукупністю послідовних, взаємопов'язаних дій викладача та студента. Підгрунтям цього процесу є об’єднання навчального матеріалу з різних освітніх галузей навчання в єдину «знаннєву» парадигму. Розглядаючи означений курс в аспекті його інтегрованості, ми привертаємо увагу викладачів до:

- необхідності здійснення кореляції між знаннями та практичними вміннями, що студенти отримують на заняттях із загального фортепіано й у процесі опанування дисциплін фахового спрямування;

- осягнення логіки формування наскрізних умінь та ключових фахових виконавських навичок на уроках із загального фортепіано;

- пошуку та встановлення змістових зв'язків між блоками навчальної інформації;

- організації навчання на основі об'єднання різних інструментально-виконавських засобів реалізації засвоєного вміння, наприклад: артикуляція, звукоутворення, побудова драматургічної концепції музичного твору тощо. 
Варто зазначити, що загальне фортепіано за програмою державних вищих музичних закладів України зазначене як «Загальне та спеціалізоване фортепіано». Розподіл на дві дисципліни («Загальне фортепіано» та «Спеціальне фортепіано») передбачає таке: ознака «загальне» охоплює студентів-інструменталістів, вокалістів та хорових диригентів; а «спеціалізоване» - теоретиків, музикознавців, композиторів, культурологів.

Оцінюючи особливості формування вмінь гри на фортепіано, Н. Гаріпова, С. Денисова, Н. Мосенко, визначають дві групи спеціалістів, для яких опанування піаністичної майстерності не є фаховою підготовкою. Виявляючи різні рівні адаптивності до гри на фортепіано інструменталістів та неінструменталістів, учені акцентують увагу на способах формування «звукотворчої волі» й особливостях звукодобування.

У результаті порівняння адаптивних здібностей щодо гри на фортепіано серед інструменталістів, вокалістів та хормейстерів, представників музикознавчих і теоретичних дисциплін Н. Вогралік, 3. Йовенко, Н. Кузнєцова, П. Хазанов, Г. Ципін, Т. Цокало, К. Шалімова доходять висновку про більш низький рівень пристосованості до фортепіанно-виконавської діяльності студентів вокальних спеціалізацій.

Запропонований нами умовний розподіл студентів-непіаністів на три групи (I - музикознавці, композитори та хорові диригенти, II - інструменталісти, III - вокалісти) базується на таких загальних особливостях опанування вмінь гри на фортепіано, як: усвідомлення важливості формування фортепіанно-виконавських умінь у контексті їхнього зв'язку зі здобутками професійної спрямованості; засоби подолання технічних складнощів виконання; досвід довишівської фортепіанної підготовки; досвід сприймання емоційно-образної сутності музики; рівень сформованості навичок самостійного аналізу творів; розвиненість здатності до слухового уявлення не тільки нотного, а й звукових фрагментів; ступінь володіння принципами організації рухового процесу: постановкою рук, м'язовою, суглобною та нервово-м'язовою системами; рівень автоматизації в застосовуванні різних прийомів музичної виразності (legato, staccato, трелі, арпеджіо, пасажі тощо); наявність відчуття контакту із клавіатурою; раціональність емоційно-психологічних та фізіологічно-енергетичних затрат.

Отже, постає необхідність розгляду отриманих під час навчання у класі «Загального та спеціалізованого фортепіано» умінь, що набувають практичної значущості у професійному зростанні, розширенні виконавської спеціалізації, тобто «умінь, що породжують нові вміння».

Непіаністам опанування гри на фортепіано надає можливість розвитку: музично-стильових відчуттів на основі знайомства з українським і світовим музичним репертуаром; музичної пам'яті та почуття ритму; слухового та тактильного осягнення багатоголосної фактури; звуковисотності слуху завдяки опануванню темперованого звукоряду фортепіано; виховання вмінь прослуховування фактури за горизонталлю та за вертикаллю, розвиток мелодичного, гармонічного, поліфонічного та тембродинамічного слухів; підвищення якості самостійної роботи студентів над музичним текстом.

Серед перелічених умінь варто звернути особливу увагу на перспективні можливості розвитку у студентів внутрішнього відчуття багатоголосся. Відчуття багатоголосся відіграє важливу роль у формуванні музичного мислення музикантів усіх спеціалізацій, але особливого значення воно набуває у творчій діяльності вокалістів, духовиків, які, ураховуючи особливості інструмента, завжди обмежені рамками одноголосного виконання. Струнні смичкові інструменти здатні до оперування багатоголоссям, але їхні можливості не можуть порівнюватись із роялем.

Багатоголосна фактура створює умови для розвитку слухових якостей студентів: темперований звукоряд фортепіано стає незамінним помічником у формуванні звуковисотності слуху, слухового контролю за чистотою інтонації, що є особливо значущим для студентівструнників, духовиків, вокалістів. Водночас особливості фортепіанної фактури дозволяють виховувати почуття звуковисотності не тільки окремих звуків, а й у музично-вертикальній площині. Посилаючись на А. Островського, який вказував на інтонаційну чистоту як результат і умови виховання слуху, варто підкреслити результативну цінність опанування темперованого звукоряду фортепіано студентами-непіаністами [12].

Особливістю музичного слуху, як зауважує О. Колосовська, є наявність його різновидів, як-от: гармонічний - уміння чути вертикальні співзвуччя; поліфонічний - уміння чути одночасне проведення двох та більше голосів; звуковисотний - уміння розрізняти звуки за властивою їм висотою, тембровий - спроможність чути особливий характер чи забарвлення звуку, голосу чи інструмента; ритмічний - навички розпізнання часової організації музичного твору [8]. 
Гра на фортепіано створює унікальні можливості щодо розвитку поліфонічного слуху. Але в переважної кількості тематичної наукової літератури йому надається визначення в об’єднанні з багатоголоссям. На наш погляд, уміння, на які впливає якість поліфонічного слуху, становлять для теоретиків, композиторів та хорових диригентів найвагомішу частину курсу навчання за їхніми спеціалізаціями. Для всіх інструменталістів можливість уяви твору, що виконується, у загальній палітрі сплетіння голосів - це підйом, уважає О. Колосовська, на високий щабель інтелектуальної, творчої роботи [8].

Щодо розвитку музичної пам'яті та почуття ритму під час навчання можна сказати таке. За технічною характеристикою, фортепіано - струнно-ударно-клавішний інструмент, його репертуар не тільки надає найширшу можливість знайомства 3 ритмічними стилями, але й ілюструє практично все розмаїття відгалужень стильових явищ. На думку Г. Ципіна, музична пам'ять цілком залежить від рівня сформованості музичного слуху та музично-ритмічного відчуття [18]. Розвитку ритму також сприяє гра в ансамблі, що є однією зі складових частин дисципліни «Загальне та спеціалізоване фортепіано».

Також важливим умінням для студентів усіх спеціалізацій є опанування культури гри ансамблем у рамках означеного предмета. Р. Гольдфейн підкреслює вагомість цього виду навчання для оркестрантів: колективний характер роботи, підпорядкованість свого виконання вирішенню загального завдання, отримання знань щодо специфіки гри 3 духовиками (урахування вдиху), зі струнниками (встановлення єдиних штрихів) [3, с. 20-26]. Саме гра ансамблем сприяє формуванню тембродинамічного слуху, що практично втілюється в уміннях знаходити баланс між динамічними можливостями рояля та духовими чи струнними інструментами. Навіть студентів, що за основною спеціалізацією (духові або народні інструменти) мають змогу вдосконалювати свої навички гри у складі оркестрів, гра акомпанементів стимулює звернути увагу на специфіку колективних форм виконавської діяльності. Цікаво, що за програмою курсу на таких заняттях студентам насамперед пропонуються до вивчення твори, де солірує інструмент, який $\epsilon$ для студента основним. Змістом ансамблевої гри для хормейстерів стає опанування прикладів і хорових партитур, для оркестрантів - творів симфонічного жанру, що доповнює знання із предмета «Симфонічне диригування». Бажання охопити якомога більший репертуар потребує, за висловом Г. Ципіна, умінь ескізного проходження творів, навички гри з нот [17].

Завдання курсу «Загальне та спеціалізоване фортепіано» для студентів теоретико-композиторського факультету полягає в залученні їх до сфери власного виконавства й інтерпретаційних процесів, на противагу теоретизації категорій, явищ та процесів, що вивчає музикознавство.

Важливим моментом щодо переваги інтеграційного змісту дисципліни «Загальне та спеціалізоване фортепіано» є взаємний вплив набутих умінь. Так, наприклад, під час гри ансамблем партії фортепіано студент водночас набуває вмінь, що мають своє продовження в іншій формі - грі акомпанементів. Поряд з усіма спеціальностями найбільш позитивний вплив гри акомпанементу на вдосконалення професійно-виконавських умінь відчувають вокалісти, унаслідок використання їхнього професійного репертуару.

Ретроспективний аналіз науково-теоретичної, методичної літератури із проблеми формування виконавських умінь гри на фортепіано під час занять із дисципліни «Загальне та спеціалізоване фортепіано» дає змогу сформулювати такі висновки:

- виконавські вміння гри на фортепіано у класі загального та спеціалізованого фортепіано визначаються якістю сформованості компонентів інтерпретаційної діяльності, що формуються у процесі виконання фортепіанних творів; базуються на досвіді, особистісних психофізичних якостях, музичних здібностях та впливають на професійне становлення студентів;

- розвиток умінь гри на фортепіано є необхідним компонентом музичного навчання студентів за всіма спеціалізаціями;

- специфіка викладання дисципліни «Загальне та спеціалізоване фортепіано» базується на принципах розвивального й інтегрованого навчання, які позитивно впливають на музичне виховання студентів, забезпечують розвиток професійно значущих теоретичних знань, інтерпретаційних умінь, необхідних для вдосконалення виконавської майстерності в рамках основної спеціалізації;

- доцільність використання методів роботи у класах загального та спеціалізованого фортепіано зумовлено вимогами та специфікою навчання у класі з основної спеціалізації. 


\section{СПИСОК ЛІТЕРАТУРИ}

1. Амфитеатрова-Левицкая А. Воспоминания о Московской консерватории. Москва : Музыка, 1966. $121 \mathrm{c}$.

2. Выгодский Н. Методическая хрестоматия по курсу общего фортепиано. Москва : Гос. муз. изд., 1935. 191 с.

3. Гольдфейн Р. Профилирующий раздел - важное звено в преподавании курса фортепиано. Проблемы художественного творчества в аспекте исполнительской и педагогической деятельности : сборник статей по материалам Всероссийских научных чтений, посвященных Б.Л. Яворскому, г. Саратов, 24-25 ноября 2016 г. Саратов, 2017. 176 с.

4. Давидовський К. Застосування сучасних методів розвитку фортепіанної техніки на уроках загального фортепіано : методичні рекомендації для викладачів музичних училищ України. Київ : Музична Україна, 1992. 24 с.

5. Загорный Н. Фортепианная игра как вспомогательный в музыкальном образовании предмет : опыт методического обоснования общего курса игры на фортепиано. Ленинград : НКПС им. Т. Лоханкова, 1928. 58 с.

6. Йовенко 3. Общее фортепиано : вопросы методики. Киев : Музична Україна, 1989. 99 с.

7. Коленко К. Особливості методики викладання фортепіано в педагогічному коледжі. Соціум. Наука. Культура. Мистецтво. URL: http://intkonf.org/kolenko-k-i-osoblivosti-metodikivikladannya-fortepiano-v-pedagogichnomu-koledzhi/.

8. Колосовська О. До питання основних складових у розвитку музиканта-інструменталіста у процесі навчання: актуальні питання гуманітарних наук. Міжквузівський збірник наукових праць молодих вчених Дрогобицького держсавного педагогічного університету імені Івана Франка. 2015. Вип. 13. С. 111-115.

9. Лось О., Сергеєва Л. Особливості методичного забезпечення курсу «Додатковий музичний інструмент» (фортепіано) у навчальних закладах педагогічної освіти. Психолого-педагогічні науки : збірник наукових праць Ніжинського державного університету імені М. Гоголя. Ніжин, 2011. № 6. C. $94-96$.

10.Новицька О. Деякі особливості викладання дисципліни «Загальне фортепіано» у вищих навчальних закладах : психолого-педагогічний аспект. Проблеми загальної та педагогічної nсихологіï : збірник наукових праць Інституту психології ім. Г.С. Костюка Національної академії педагогічних наук України. Київ, 2010. Т. ХІІ. 6. С. 248-258.

11.Ныркова В. Курс фортепиано для музыкантов разных специальностей : История и методологические принципы. Вопросы истории, теории, методики. Москва : Музыка, 1988. 48 с.

12.Островский А. Методика теории музыки и сольфеджио : пособие для педагогов. Ленинград : Музыка, 1970. 296 с.

13. Рубинштейн А. Музыка и ее представители. Санкт-Петербург : Союз художников, 2005. 160 с.

14.Стандарт вищої освіти за спеціальністю 025 «Музичне мистецтво» для першого (бакалаврського) рівня вищої освіти : наказ Міністерства освіти і науки України від 24 травня 2019 р. № 727. URL: https://mon.gov.ua/storage/app/media/vishcha-osvita/zatverdzeni\%20standarty/2019/05/28/025muzichne-mistetstvo-bakalavr.pdf.

15.Тарчинська Ю. Формування у студентів-інструменталістів навичок виразного виконання у процесі вивчення курсу «Загальне фортепіано» : автореф. дис. ... канд. пед. наук: 13.00.02. Київ, 2002. $19 \mathrm{c}$.

16.Фейнберг С. Пианизм, как искусство. Москва : Музыка, 1969. 608 с.

17.Хазанов П. А. Интеграция курса фортепиано со специальными дисциплинами в процессе подготовки музыкантов-исполнителей. Современные проблемы науки и образования. 2017. № 4. URL: https://www.science-education.ru/ru/article/view?id=26664.

18. Цыпин Г. Обучение игре на фортепиано : учебное пособие для студентов педагогических институтов по специальности 2119 «Музыка и пение». Москва : Просвещение, 1984. 176 с.

\section{REFERENCES}

1. Amfiteatrova-Levickaya, A.N. (1966). Memories of the Moscow Conservatory. Moscow: Muzyka. [in Russian].

2. Vygodskij, N.Ya. (1935). Methodical reader on the course of general piano. Moscow: Gos. muz. izd. [in Russian].

3. Gol'dfejn, R.M. (2017). The majors section is an important link in teaching the piano course. Problemy hudozhestvennogo tvorchestva $v$ aspekte ispolnitel'skoj $i$ pedagogicheskoj deyatel'nosti. Saratov. [in Russian].

4. Davidovs'kij, K.Yu. (1992). Learning of the most advanced methods of developing piano technology in the lessons of the foreign piano: metodichni rekomendacii dlya vikladachiv muzichnih uchilishch Ukraini. Kyiv: Muzichna Ukrayina. [in Ukrainian].

5. Zagornyj, N.N. (1928). Piano playing as an auxiliary subject in musical education: the experience of methodological substantiation of the general course of playing the piano. Leningrad: NKPS im. T. Lohankova. [in Russian]. 
6. Jovenko, Z.N. (1989). General piano: questions of methodology. Kyiv: Muzichna Ukrayina. [in Ukrainian].

7. Kolenko, K.I. Features of the methodology of the piano in the pedagogical college. Socium. Nauka. Kul'tura. Mistectvo. URL: http://intkonf.org/kolenko-k-i-osoblivosti-metodiki-vikladannya-fortepianov-pedagogichnomu-koledzhi/.

8. Kolosovs'ka, O. (2015). On the question of the main components in the development of a musicianinstrumentalist in the learning process: current issues of the humanities. Mizhvuzivs'kij zbirnik naukovih prac' molodih vchenih Drogobic'kogo derzhavnogo pedagogichnogo universitetu imeni Ivana Franka. 13, 111-115. [in Ukrainian].

9. Los' O.M., Sergeyeva L.O. (2011). Features of methodical support of the course "Additional musical instrument" (piano) in educational institutions of pedagogical education. Psihologo-pedagogichni nauki: zbirnik naukovih prac' Nizhins'kogo derzhavnogo un-t im. M. Gogolya. 6. 94-96. [in Ukrainian].

10. Novic'ka, O.V. (2010). Some features of teaching the discipline "General Piano" in higher education: psychological and pedagogical aspect. Problemi zagal'noyi ta pedagogichnoyi psihologiyi. XII. 248-258. [in Ukrainian].

11. Nyrkova, V. (1988). Piano course for musicians of different specialties: History and methodological principles. Voprosy istoriii, teorii, metodiki. Moscow: Muzyka. [in Russian].

12. Ostrovskij, A.L. (1970). Methods of music theory and solfeggio: a guide for teachers. Leningrad: Muzyka. [in Russian].

13. Rubinshtejn, A. (2005). Music and its representatives. St. Petersburg: Soyuz hudozhnikov. [in Russian].

14.The standard of sanctuary for specialty 025 "Musical mystery" for the first (bachelor's) sanctuary of sanctuary // Nakaz Ministerstva osviti i nauki Ukrayini vid 24.05.2019 r. № 727. URL: https://mon.gov.ua/storage/app/media/vishcha-osvita/zatverdzeni\%20standarty/2019/05/28/ 025-muzichne-mistetstvo-bakalavr.pdf. [in Ukrainian].

15. Tarchins'ka, Yu.G. (2002). Formation of students-instrumentalists skills of expressive performance in the process of studying the course "General Piano": avtoref. dis kand. ped. nauk : 13.00.02. Kyiv. [in Ukrainian].

16. Fejnberg, S.E. (1969). Pianism as an art. Moscow: Muzyka. [in Russian].

17. Hazanov, P.A. (2017). Integration of the piano course with special disciplines in the process of training musicians Sovremennye problemy nauki i obrazovaniya. URL: https://www.science-education.ru/ru/ article/view?id=26664. [in Russian].

18. Cypin, G.M. (1984). Piano training. Moscow: Prosveshcheniye. [in Russian].

УДК 780.6

DOI https://doi.org/10.31723/2524-0447-2020-30-1-21

Сергей Григорьевич Дикарев

ORCID: 0000-0002-7400-6099

аспирант кафедры интерпретологии и анализа музыки

Харьковского национального университета искусств имени И. П. Котляревского

dikarev.serch1808@gmail.com

\section{РОЛЬ КОНТРАБАСА КАК КАМЕРНО-СОЛЬНОГО ИНСТРУМЕНТА В МУЗЫКЕ КШИШТОФА ПЕНДЕРЕЦКОГО (НА ПРИМЕРЕ КОНЦЕРТНОГО ДУЭТА ДЛЯ СКРИПКИ И КОНТРАБАСА)}

\footnotetext{
Целью работы является выявление специфики роли контрабаса как камерно-сольного инструмента в музыке Кшиштофа Пендерецкого (на примере Концертного дуэта для скрипки и контрабаса). Методология исследования опирается на использование аналитического, жсанрового и структурнофункционального методов исследования. Научная новизна - обоснование полифункционального значение контрабаса в камерно-инструментальном творчестве Кшиштофа Пендерецкого. Выводы. В Концертном дуэте для скрипки и контрабаса К. Пендереикого раскрываются не только творческое мастерство композитора, но и тембровая корреляция таких одновременно столь схожих и столь различных струнно-смычковых инструментов, как скрипка и контрабас. Контрабас в Концертном дуэте для скрипки и контрабаса К. Пендереикого имеет полифункциональное значение. С одной стороны, композитор оставляет контрабасу его традиционную роль гармонической и басовой основы, используя оркестровое пициикато. С другой стороны, партия контрабаса усложнена широкими скачками в высоком регистре, которые дают возможность контрабасу ощутить себя на месте солирующей скрипки. Виртуозность
}

(C) Дикарев С. Г., 2020 